\title{
DYNAMIC SYSTEMS THEORY AND SPORTS TRAINING
}

\author{
Carlota Torrents ${ }^{1}$, Natàlia Balagué ${ }^{2}$ \\ National Physical Education Institute of Catalonia, University of Lleida ${ }^{1}$, Lleida, National Physical \\ Education Institute of Catalonia, University of Barselona², Barcelona, Spain
}

\begin{abstract}
Carlota Torrents. PhD Candidate of National Physical Education Institute of Catalonia, University of Lleida. The field of scientific research — the application of composite dynamic systems theory in the process of sports training.
\end{abstract}

Natalija Balague. Professor of National Physical Education Institute of Catalonia, University of Barcelona. The field of scientific research — the application of composite dynamic systems theory in scientific research and sprots science.

\begin{abstract}
Classical training theory is deeply influenced by a mechanical conception and a Cartesian view of athletes. Although the natural limitations of this classical approach are recognized, training methods are largely based on it. Nowadays, Dynamic Systems Theory is offering new tools to explain the behavior of the neuromuscular system and very useful principles to be applied to sports training (Kelso, 1999; Kurz, Stergiou, 2004). Instead of being thought of as machines, athletes are considered as complex dynamic systems, self-organized and constrained by morphological, physiological, psychological and biomechanical factors, the properties of the task and the environment. Due to this complexity, they are noticeably dependant on their initial condition and the distribution of attractors, showing fluctuations when passing from one attractor to another. The mechanism of adaptation to training, observed as a selforganization process, is transforming modern training stimuli and expected performance responses. Training loads should encourage the process of self-organization in an integrated, overall way, changing the environment and the conditions to constrain the subject in the desired direction of the training process. The principle of individuality not only focuses on inputs but also on the outputs promoting the variability of the athlete's responses to each changing competition and training situation.

In conclusion, Dynamic Systems Theory is changing the view of mechanisms of adaptation to training and introducing important changes into performance targets and training methods, challenging scientists and modern coaches to find suitable solutions to optimize the training process.
\end{abstract}

Keywords: self-organization, attractor, fluctuation, variability, stability.

\section{INTRODUCTION}

$\mathrm{S}$ ports performance and training science has traditionally been deeply influenced by the mechanical conception of human beings. Although the need to integrate all aspects of training is constantly mentioned and more holistic proposals are sought, the dominant conceptual structure is still based on a Cartesian view. It conceives the organism as a machine divided into parts and performance as the sum of different qualities. Besides this, the computer metaphor is used to explain the adaptation process and determine the most commonly applied training methods.

Following classical training theory, it is expected that an input (the training stimulus) should produce, after the central processing of the information, an output (the performance response). This response has to be previously known by the subject and programmed by the coach (no correct response is expected otherwise). As there is generally just one possible correct response (the right 
technique, the right tactics ...) any deviation from this response will be considered as an error that will be corrected through repetition (necessary to achieve the automation of the correct response). Sports technique is commonly trained by guiding athletes to copy and reproduce the correct model; conditional training is focused on supporting and enhancing this specified technique, and tactical training is normally planned to produce previously determined strategies, which are expected to adapt to the opponent's weakest points, minimizing spontaneous decision-making by the team.

Sports training is also influenced by cognitive theories, assuming athletes are provided with regulator systems that allow them to constantly compare their current performance with the rehearsed objective in order to avoid undesirable errors. The program will be improved by practice and progress will be made through repetition and comparing execution with the reference response (Davids et al., 1994; Ingvaldsen, Whiting, 1997, Temprado, Laurent, 1999).

What are the correct inputs or training loads to improve this program, which defines previously specified correct outputs? Inputs should be very analytical, as they must correct any small deviation, based on division into components and focused towards microscopic parameters in order to improve isolated functions. They should be very specific, as they have to inform the program about the structure of the motor action; big enough to produce a significant change in response and correct possible errors, and they should increase progressively in order to achieve continuous performance development. The research available has empirically demonstrated these principles. In strength training, for instance, specificity is often postulated, arguing for the importance of training in the specific angle of the sports movement (Weir et al., 1994), the correlation of the type of training with the type of gain in strength (Rutherford et al., 1986) or with specific speed (Ewing et al., 1990). However, the tests used to confirm these hypotheses are based on closed tasks and are consequently a long way from reflecting the constantly changing reality of sports competition.

This classical model seems to be not satisfactory, because it does not consider the selforganizing capacities of athletes and teams and enormously simplifies the complex nature of human movement and sports performance. Some athletes can frequently be observed generating new movement patterns and improving their performance with very little or no practice; even responding with different models, which have not been established previously by the orthodox technique outlined by the coach. By contrast, despite repeating the established pattern, other athletes do not achieve this, even if they reproduce it very faithfully.

The complexity of human beings has been emphasized over the last century with the appearance of new scientific theories that have influenced biological and social sciences. It has recently been suggested that Dynamic Systems Theory (DST), which explains the organization and emergence of human movement and has been applied mainly to motor control and learning (Kelso, 1999), could to be applied to sports training. The concept of the human beings as complex dynamic systems changes the mechanical view of athletes and the adaptation process based on the computer metaphor. This change in paradigm affects training proposals stemming from classical training theories and leads to a demand for its principles to be updated.

\section{DST AND HUMAN MOVEMENT}

DST is a mathematical theory that has been applied to all kinds of phenomena (Abraham, Shaw, 1992; Andronov, Chaikin, 1937). DST applied to human beings can be defined as a theory of change that tries to capture, study and understand the structural transitions and behavior of the system together with the environment (Corbetta, Verijken, 1999). Human beings are complex dynamic systems and are effectively organized following the principles of DST (Haken et al., 1985). These principles suggest that movement patterns arise from the synergetic organization of the neuromuscular system based on morphological and biomechanical factors, the environment and the task constraints. Complex interaction between these components participating in motor behavior and the self-organization process will produce the emergence of an individual response (Kelso, 1999; Kurz, Stergiou, 2004; Thelen, Smith, 1998).

The system organizes itself, although there is no agent inside the system doing the organizing (Kelso, 1999). All parts of the system are affected by the other parts and by the interaction between them. Self-organization and motor patterns 
will be defined by collective variables of the system or order parameters and will be constrained by the control parameters that will produce the change (Kelso, 2000). DST research has shown how a small change in a control parameter that constrains the system can lead to abrupt changes in the overall behavior of that system. This control parameter can come from the environment (Carson et al., 1995; Diedrich, Warren, 1995; Haken et al., 1985; Kelso, Jeka, 1992; Large, 2000; Stergiou et al., 2001), from the internal processes of the subject (Pellecchia, Turvey, 2001) or from interaction with other subjects (McGarry et al., 2002; Schmidt et al., 1990; Schmidt et al., 1999; Treffner, Kelso, 1999).

Practice or exposure to certain environmental conditions can guide, facilitate or alter the formation of differentiated movement patterns, depending on the initial conditions of the system (Angulo-Kinzler, 2001; Ulrich et al., 1998; Thelen et al., 1993). DST research has suggested noticeable dependence on the initial conditions in the behavior of dynamic complex systems and the presence of states attracting the system called attractors (Abraham, Shaw, 1992).

This approach that has arisen to explain human movement can help us to improve training methods. DST offers various tools that allow the behavior of the neuromuscular system to be expressed theoretically in low-dimensional terms and gives information about the organization of the system (Kurz, Stergiou, 2004). Their principles can be also applied to sports science research: firstly to the study of human movement (Kugler, Kelso, Turvey, 1980) and extended to motor control and learning (see Kelso, 1999, for a review), to the study of posture (Bardy et al., 2002; Dijkstra et al., 1994; Marin et al., 1999; Oullier et al., 2002; Riccio, 1993), to physiology (Amazeen et al., 2001; Bernasconi, Kohl, 1993; Bramble, Carrier, 1983; Garlando et al., 1985; Kantz, Kurths, 1998) and recently to training methods (Buekers et al., 1999; Davids et al., 2000; Delignières et al., 1998; McGarry, Franks, 1996; McGarry et al., 1999, 2002; Schöllhorn, 2000; Torrents et al., 2005 in press).

Conclusions of this research suggest to us a change in the classical view of the whole process of training, and challenge modern coaches to find more appropriate training methods able to overcome the natural limitations of the current ones.

\section{DST AND OUTPUT}

The concept of the correct or right response has been fundamentally changed by the new paradigm. According to the research results obtained by applying DST to the study of human movement, the athlete does not need to know the solution of a new task beforehand. A complex interaction between the components participating in the motor behavior, the task and the process of self-organization will produce the emergence of the right response. Practice or exposure to certain environmental conditions can guide, facilitate or alter the formation of differentiated movement patterns, depending on the initial conditions of the system. The presentation of the right model and the instructions intended to describe and guide it can even interfere negatively in the learning process (Hodges, Franks, 2002; Wulf, Prinz, 2001). An ideal technique will exist for each situation and for each individual. For this reason, it will be necessary to train subjects to adapt to change instead of copying an external or foreign solution.

The concept of "error" has changed since the appearance of DST in learning and training. The presence of fluctuations of the system in the transition zone between two attractors observed in coordination dynamics (Kelso, 1999) and the discovery that variability can be a biological marker of healthy responses (Bernaola-Galván et al., 2001; Hamill et al., 1999; Selles et al., 2001) have led to these fluctuations being interpreted as necessary for adaptation and learning. There will be variations of the coupling of the degrees of freedom of the system because of its global response (changes in the environment or task) and local disturbances (Kurz, Stergiou, 2004; Thelen, Ulrich, 1991). However, the system will be attracted to a state of equilibrium, to the attractor, and the exploration of new neuromuscular solutions will be necessary to adapt the response to any change in the constraints (Schmidt et al., 1992).

Variability and fluctuations will be now desirable, so ensuring that the system is exploring the whole state space and can discover the right response or improve its adaptation system. For this reason, the individuality principle not only has to be input-oriented (selection of the individual stimuli to get the previously defined response) but also output-oriented (promoting different, variable and individual solutions) (Balague, Torrents, 2005). This individuality of the responses is also 
valid for a team, which will respond depending on the interactions between all the players, which will produce many more constraints that in individual sports.

In fact, variability is inherent within all biological systems, and it will not be possible to expect any identical responses (Bernstein, 1967) because of the non-linear interactions between the parts of the system.

\section{DST AND THE ADAPTATION PROCESS}

Effective organization of the multiple degrees of freedom present in the neuromuscular system requires non-linear processes. Self-organization will determine the synergic emergence of individual adaptation responses. At the same time, athletes will not be considered as simple receivers of stimuli either, but rather as playing a leading role the training process - a part that will constrain it. For this reason, they should be more involved in the overall training process.

DST research has suggested the noticeable dependence on initial conditions in the behavior of dynamic complex systems and the presence of states that attract the system - the so-called attractors (Abraham, Shaw, 1992). When the system is disturbed, it spontaneously returns to the attractor or stable state after the disturbance subsides. DST applied to human movement has shown that this behavior also characterizes coordination dynamics (Haken et al., 1985). Movement patterns are the result of all the components that affect the system working together to achieve a functional outcome that meets the constraints of the system (Kelso, 1999; Kurz, Stergiou, 2004). The conjunction of the inherent properties of the system and experience configure the distribution of the attractors. These can be modified when the system is globally or locally disturbed enough to remove the attractors.

As a result, training programs should consider each athlete's individual characteristics and the individual context the athlete interacts with. As has been mentioned, this individuality should also be present when proposing stimuli and when valuing the responses. This can be achieved by letting the athlete participate actively in the training process (Nitsch, Munzert, 2002). Instead of defining the right solutions, instructions should be addressed to external parameters related to the trajectory of the movement or to the result of that movement on the environment (Mechsner, 2004; Wulf, Prinz, 2001), and should emphasize the self body awareness.

Related to this concept, the athlete's initial state should be considered. The process of learning or adapting to new movements or sports techniques will be constrained by the spontaneous movements that arise in each athlete (the distribution of the attractors). They will affect the progress and the stability of the adaptation process. By studying cyclical movements, the importance of destabilizing the existing attractors in order to learn new coordination patterns (Milliex et al., 2003) has been shown. This is observed also in sport when we want to modify certain aspects of a well-known technique. A coach's instructions about the athlete's "errors" will not be enough. Instead, other strategies must be sought so that the subject loses the "habit" he or she already has. Some examples of facilitators will be explained in section 5 .

Taking into account that no model will be demonstrated, athletes will not have a preconceived idea of the movement. This will make it easier for them to be more attentive to the sensations and reactive forces experienced and therefore more open to understanding their own organization systems.

In addition, the training process for a team can follow the same principles, as the team will also be a dynamic complex system per se, which will have the capacity to self-organize. The interaction between all the players will produce spontaneous solutions that will constrain the adaptation process at the same level as the interaction of the parts does in an individual system (Fitzpatrick et al., 1996; McGarry et al., 2002; Oullier et al., 2003; Schmidt et al., 1990; Schmidt et al., 1999; Treffner, Kelso, 1999). It will be necessary to destabilize the emerging attractors in order to create new responses and seek the increasing capacity of the system to adapt to constantly changing situations.

\section{DST AND INPUT}

The training stimuli (load) that will be applied to the athlete are also constrained by the theoretical model of human behavior. The load will not be considered as something external to the system, but a constraint that will be present in all the factors affecting it. These factors can be inherent in the biological system (changing some conditions 
that can affect the biomechanical or biological factors), or it can come from the environment (spatial and temporal configuration of the events) or from the task constraints (the traditional concept of load). The DST offers empirical proposals to be applied to all these factors.

\section{TASK CONSTRAINTS}

Classical training theory is mostly based on the design of the ideal task constraints. Training programs are usually based on division into components and on the improvement of the isolated functions and focused towards microscopic parameters. The complexity of dynamic systems suggests that this should be incorporated into an overall view. Training methods can be more focused on a certain aspect, but always bearing in mind the influence of the whole organism.

Classical conditional training is clearly influenced by reductionism. In strength training, for instance, it is common to train each muscle independently. Also, many athletes forget the stability muscles. Some machines are designed to isolate the work of specific muscles, even adding external supports to facilitate the adaptation of the areas of the body considered as weak. This type of protection can be very beneficial in avoiding injuries in beginners or for very specific objectives, but the exclusive use of this type of practice will lead to an athlete lacking in important aspects.

Stretching training is also often based on the division of muscular groups and on passive and static methods. However, the stretching of a muscle produces compensations in the rest of the muscular chain this muscle belongs to, and the exercise will not be fully effective if the whole chain is not stretched simultaneously (Souchard, 1996). Moreover, stretching could be combined with strength training at the same time, in order to achieve a truly functional body. This combination can work by increasing the width of the movements or practicing active and dynamic stretching. In this case, technical training can also be added.

Finally, overall task training is also suggested, without breaking them down into parts. K. Davids et al. (1999) studied the volleyball serve in expert players. They analyzed the time series of the displacement of different joints and observed a strong phase relationship between adjacent pairs of joints (hip-shoulder, shoulder-elbow, elbow-wrist). This suggested a synergetic organization of the action.
Training by breaking the serve down into parts leads to the exploration of the wrong region of the state space.

In an analogous situation, training a team should always emphasize the overall responses of the system instead of developing isolated individual actions. At least, these individual actions should always be immersed in the overall system.

Another concept that should be adapted to the new view is the principle of variability of load. This considers changing different parameters related to the volume, intensity and type of contraction. However, the need to change the structure of the exercise or to train movements that do not correspond with what is considered to be the correct technique are not assumed.

The consequences of DST application in training propose this kind of variation, which, surprisingly, is in agreement with classical training theory in some aspects. It is necessary to stimulate the subject to lose his or her "fitness state" and receive a supercompensation. That is to say, it is necessary to destabilize the distribution of the attractors so that the subject can reorganize and acquire a new state. The concept of supercompensation normally refers to conditional training, but this does not seem to keep in mind the need to adapt the technique to an infinite number of situations and the athlete's need to be optimized by making his or her systems more adaptable and flexible.

Some well-known learning methods take this need into account. This is the case with the M. Feldenkrais's method. This author seeks to extend and to tune the general control that one has on the muscles, offering the opportunity to explore movements for oneself and to discover the new possibilities by means of clearly defined exercises. Each individual learns how to judge what is comfortable and easy for him or her. The exercises are very different to each other and, in practicing, the subject is aware of the tensions and the lack of freedom of the movement. Practitioners go through unusual positions to explore new possibilities and to disorganize the nervous system's customs or habits (Feldenkrais, 1985). In the theoretical base of this method we find many parallelisms with DST, as described by P. A. Buchanan and B. D. Ulrich (2001). Respecting the self-organization principle, M. Feldenkrais considers that the students have self-organizing behaviors that emerge from the conjunction of extrinsic and intrinsic elements. 
He also respects the great variety of systems that affect the behavior and emphasizes the continuous interaction between the perception and the action. Among the practical proposals offered by this method, those that we consider most interesting for application to the optimization of training are:

- Manipulation of the environment to destabili ze the existing attractors and to help new ones emerge. According to $\mathrm{M}$. Feldenkrais, this can be achieved by means of different strategies:

- Alteration of space orientation

- Alteration of the environment using instruments (rollers, Swiss balls ...)

- Modifying the support surface: practice in water, in more stable positions...

- Reducing learning effort. At the beginning of the learning process, the M. Feldenkrais's method proposes minuscule movements of the body, as these can cause changes in the organization of the overall movement of the body.

- Encouraging the emergence of individual patterns and not copying those considered as "normal".

Some studies based on DST reach similar conclusions. D. Delignières et al. (1998) carried out a comparative study between the coordinative patterns of beginner gymnasts and experts. They concluded that coaches should not only notice the "errors" that their athletes show. They should observe their intrinsic dynamics and to help them to destabilize them, and explore the movement in order to find a good solution. Studies related to child development also propose the destabilization of the learner's attractors to assist the emergence on new motor patterns (Corbetta and Verijken, 1999; Thelen et al., 1996).

The proposal of varying stimuli for learning was already mentioned by N. A. Bernstein (1967). This author considered that an expert should control the task in all the possible situations. As conditions are never the same, practice should be carried out not only to automate the task, but to develop flexible strategies to adapt to environmental changes. For N. A. Bernstein, practice did not consist of repeating the possible solution, but of the process of solving the problems by means of techniques that were modified in each "repetition". Practice will be a particular type of repetition without repetition.

Later on, R. A. Schmidt's variable practice (Schmidt, 1975) and contextual interference
(Carnahan, Lee, 1989; Hall, Magill, 1995; Shea, Morgan, 1979) also proposed the variation of tasks during learning. Training should also not exclusively emphasize repetition but rather provide athletes with a wide spectrum of situations allowing them to generate changes in coordination, to modify the intrinsic dynamics of the system and to provide them with a new group of experiences leading to the discovery of the final answer. However, this answer can never be fixed or static in an organism in constant change and evolution. If we consider that it is not possible to reproduce the initial conditions exactly, the repetition concept also loses its meaning.

One of the better developed propositions for varying training stimuli, respecting DST principles, is W. I. Schöllhorn's differential training (1998). According to this author, to solve the problem of individuality there are two types of solutions: to establish an ideal training model for each individual (which probably involves a difficult, expensive and possibly unachievable task) or to offer athletes a great variety of exercises to induce a process of self-organization of their learning and development. Differential training proposes this second option, taking advantage of the need to fluctuate or to produce 'errors' for learning. Fluctuations are considered as deviations from a reference point, as differences that allow the system to react and to constantly adapt to changes. These aims are different from the purpose of variable practice or contextual interference (Schmidt, 1982; Shea, Kohl, 1990; Shea, Morgan, 1979) in spite of the seemingly common position. These theories are based on a cognitive model, while the DST perspective gives another explanation to the utility of the variation in practice. It maintains that carrying out a variety of exercises helps subjects to spontaneously discover individual patterns of movement that allow them to respond more effectively. However, the variations will not be arbitrary. Instead, certain elements of the learning technique should be included in the practice (Schölhorn, Bauer, 1998).

W. I. Schöllhorn maintains that the mechanisms for which these adaptations are explained refer to interpolation, extrapolation and to self-organization. Interpolation will consist of reaching a new state that is between two in the existing space (stored movements). Extrapolation will consist of the new state being outside the space of these 
two states. These concepts come from the study of artificial neural nets (Schöllhorn, 2004).

Differential training will involve learning from differences through very versatile exercises based on:

- Variation of the initial and/or final conditions of a movement,

- Changing the magnitude of the variables,

- Changing the evolution or development of the movement regarding its absolute and relative duration and the rhythm.

These variations will be applied to the angle between joints, to the angular speed, or to the angular acceleration. We can observe that other variations are added to the proposals on variable practice, centered on the sequence of the elements of the movement, the relative timing and the relative forces, and that others from contextual interference are included. This last proposal suggests that the abilities can be improved not only by modifying temporary or quantitative aspects, but also by changing the form of the space configuration of the movement and the muscular groups involved (Magill, Hall, 1990)

Finally, W. I. Schöllhorn also proposes a progression in the variability of the stimuli, beginning with an initial variation in the geometry of the movement and then varying the speed or the acceleration, downplaying the proposals that suggest random variable practice.

W. I. Schöllhorn and collaborators (Beckman, Schöllhorn, 2003; Rein, Simon, 2003; Schöllhorn et al., 2001; Schönherr, Schöllhorn, 2003; Trockel, Schöllhorn, 2003) put into practice their proposal in different sports for improving motor actions. They made different group studies comparing traditional and differential training, and observed better improvements with the latter. They observed also a better retention and a more stabilization of the improvements in the group that trained differentially. C. Torrents et al. (2005) (in press) carried out a study of cases also comparing traditional and differential training in aerobic gymnastics. Results showed the effectiveness of differential training for this sport, but a combination of both approaches was suggested.

Differential training has been applied to technical and conditional training. However, its principles can be also applied to tactical training, as the main aim of a team will be to find effective answers to the different and always changing situations of interaction with the opponents. In fact, tactics are always variable by definition, as they are the capacity to adapt to the opponent's behavior. This variability also characterizes any sport situation, so the specificity of practice to the demands of competition or sport is better satisfied with these training methods.

Offering varied exercises has some other advantages for working in groups, as each athlete or student can reach the solution without so many instructions and become more responsible for their process. Motivational aspects are also better satisfied. Moreover, this proposal can reduce injuries caused by overload or overtraining. The most popular formula of training using hundreds of repetitions surely in most cases involves an unnecessary overload of muscles and joints, besides causing greater psychological fatigue. However, the variation of stimuli has some injury risks, and safe exercises must be suggested to athletes who know and control their own bodies.

M. J. Buekers (2000) also proposes variation of training at the beginning of sport practice, although he believes it should be reduced in later learning states, bearing in mind the demands of the specific discipline. Later on, an increase in variations should be practiced, in order to adapt the technique to different situations. This type of training will be more respectful of the athlete's individuality, as the coach will look for an understanding of the sportsperson's in order to propose the appropriate conditions (Davids, Button, 2000).

Certain sports have some rules that lay down the technique for the movement in a very specific way. The aesthetic sports, such as gymnastics, skating or synchronized swimming, are examples of this. Coaches cannot leave total freedom to athletes for discovering their more efficient way of carrying out a task. Nevertheless, they can help athletes by using the most appropriate constraints at the beginning of the learning process and varying practice conditions afterwards.

In our opinion, because of the consideration of the athlete's initial state and the stability of the attractors, more investigation is required to state whether differential training or training based exclusively on variations is the optimum stimulus for all the subject's states or all levels of training. Variations are probably very useful in destabilizing the athlete and promoting 
a change of state, making the system more flexible and more adaptive, but repetitions of the task can help to develop and stabilize attractors. Observing children's learning we see that they try to repeat the task until they get a stable pattern (Thelen, Smith, 1998).

Variability can modify inadequate structures in an overall way and develop other more appropriate ones. Training should not only be a refinement of motor actions, but also the optimization of cognitive structures integrated into the whole system. Learning will not just be a change of attractor, but rather a modification of the overall distribution of the system's attractors (Kelso, 2003).

\section{ENVIRONMENTAL CONSTRAINTS}

We have emphasized the overall view of sport training. In addition to the influence of the whole organism, it will also be necessary to bear in mind the influence of the environment (Carson et al., 1995; Diedrich, Warren, 1995; Haken et al., 1985; Kelso, Jeka, 1992; Large, 2000; Stergiou et al., 2001).

In order to facilitate the learning of a new technique it is possible to encourage the perception-action cycle by modifying the environment. An example of this modification is the one that was carried out by F. Meschner (2004 a). The vision of the movement of some flags facilitated the learning of a bimanual task. This author explains these results by means of the so-called psychological perspective, but he reaches similar practical conclusions to the DST perspective. He proposes the adaptation of the environment instead of classical repetitions. Regarding this adaptation, F. Mechsner (2004 b) highlights that the information must be perceived by the subject. For adapting the environment, we can use marks on the floor or in the space that help the system to be coupled with the reference. It is also useful to use acoustic marks, using music for instance (Large, 2000).

G. Wulf and W. Prinz (2001) suggested that instructions related to the effect of the movement on the environment are more effective than those referring to the movement, which reinforces the methodology that we propose. Nevertheless, we also consider it important for the instructions to refer to the subject's feelings when moving, as this will give proprioceptive information to the system.
The modification of the control parameters or of the environment will also facilitate the destabilization of the distribution of the attractors. Behavior will emerge without precise instructions. An example of this modification should be the decrease in the speed in carrying out a movement after it has been demonstrated in order to learn a new bimanual pattern (Carson et al., 1996). We can also modify the load or the weight that the subject should support to carry out motor actions requiring a great application of force, or to increase the subject's stability by means of some external help. This strategy is very common in gymnastic sports, using the ballet bar or the help of the coach for improving specific sports techniques.

\section{BIOLOGICAL SYSTEM CONSTRAINTS}

The initial conditions of the biological system will dramatically constrain the output. They will be defined by the distribution of attractors of the system at the precise moment of input application and depend on morphological, physiological, psychological and biomechanical factors, but the output will be also constrained by emotional and cognitive factors (Pellecchia, Turvey, 2001). All of these can be changed during the training period by the task and environmental constraints. However, they also can be changed by the time of the application of the stimuli. They can particularly be modified through motivational strategies, due to the coach's action, to environmental factors (i.e., public performance) or, obviously, to the athlete's action (Jackson, Csikszentmihalyi, 2002).

These motivational strategies are very much used in sport, probably because of their impressive influence in the performance, but there is also a possibility of changing morphological and biomechanical factors to be applied during training. The system's weight, for instance, can be changed with the use of external loads adapted to the body or with the use of external supports (belts) or training in water, i.e., in order to reduce this weight. Motor development can be also enhanced with these strategies (Thelen et al., 1996; Ulrich et al., 1998). However, these constraints can be also considered as inherent in the tasks, and not in the biological system, as they are based on external factors. 


\section{CONCLUSIONS}

DST perspective, far of being a theoretical approach which is difficult to apply to sports actions and the reality of training and competition, suggests a new view of the mechanisms of adaptation to training. Athletes and teams are considered as complex dynamic systems that respond to the infinite new situations that characterize sports competition by self-organizing their behavior within the different constraints and interacting with them. Traditional training based on the Cartesian view and on the reproduction of external and ideal models cannot encourage the overall self-organization of systems. In contrast to it, the DST approach is introducing important changes in the performance objectives and training methods. The challenge for modern coaches and scientists is to find suitable solutions for optimizing the training process.

\section{REFERENCES}

Abraham, R. H. \& Shaw, C. S. (1992). Dynamics The Geometry of Behavior. Adison-Wesley Publishing Company.

Amazeen, P. G., Amazeen, E. L. \& Beek, P. J. (2001). Coupling of breathing and movement during manual wheelchair propulsion. Journal of Experimental Psychology: Human Perception and Performance, 27 (5), 1243-1259.

Andronov, A. A. \& Chaikin, C. E. (1937). Theory of Oscillations. Princeton University Press.

Angulo-Kinzler, R. M. (2001). Exploration and selection of intralimb coordination patterns in 3-month-old infants. Journal of Motor Behavior, 33 (4), 363-376.

Balagué, N., Torrents, C. (2005). La interacción atletaentrenador desde la perspectiva de los sistemas dinámicos complejos. Revista de Entrenamiento Deportivo, XIX, 3, 19-24.

Bardy, B. G., Oullier, R. O., Bootsma, J. \& Stoffregen, T. A. (2002). Dynamics of human postural transitions. Journal of Experimental Psychology: Human Perception and Performance, 28 (3), 499-514.

Beckman, H., Schöllhorn, W. (2003). Differential learning in shot put. In W. I. Schöllhorn, C. Bohn, J. M. Jäger, H. Schaper, M. Alichmann (Eds.), European Workshop on Movement Science. Mechanics, Physiology, Psychology. Köln: Sport Buch Strauss.

Bernaola-Galván, P., Ivanov, P. Ch., Nunes, L. A. \& Eugene, H. (2001). Scale invariance in the nonstationary of human heart rate. Physical Review Letters, 87 (16), 168105.

Bernasconi, P. \& Kohl, J. (1993). Analysis of co-ordination between breathing and exercise rhythms in man. Journal of Physiology, 417, 693-706.

Bernstein, N. A. (1967). The coordination and Regulation of Movements. New York: Pergamon Press.

Bramble, D. M. \& Carrier, D. R. (1983). Running and breathing in mammals. Science, 219, 251-256.

Buchanan, P. A. \& Ulrich, B. D. (2001). The Feldenkrais method: A dynamic approach to changing motor behavior. Research Quarterly for Exercise and Sport, 72 (4), 315-323.

Buekers, M. J. (2000). Can we be so specific to claim that specificity is the solution for learning sport skills? International Journal of Sport Psychology, 31,
485-489.

Buekers, M. J., Montagne, G. \& Laurent, M. (1999). Is the player in control, or is the control somewhere out of the player? International Journal of Sport Psychology, 30, 490-506.

Carnahan, H. \& Lee, T. D. (1989). Training for transfer of a movement timing skill. Journal of Motor Behavior, 21, 48-59.

Carson, R. G., Byblow, W. D., Abernethy, B. \& Summers, J. J. (1996). The contribution of inherent and incidental constraints to intentional switching between patterns of bimanual coordination. Human Movement Science, 15, 565-589.

Carson, R. G., Goodman, D., Kelso, J. A. S. \& Elliot, D. (1995). Phase transitions and critical fluctuations in rhythmic coordination of ipsilateral hand and foot. Journal of Motor Behavior, 27, 211-224.

Corbetta, D. \& Verijken, B. (1999). Understanding development and learning of motor coordination in sport: The contribution of dynamic systems theory. International Journal of Sport Psychology, 30, 507-530.

Davids, K., Bennett, S., Handford, C. \& Jones, B. (1999). Acquiring coordination in self-paced, extrinsic timing tasks: A constraints-led perspective. International Journal of Sport Psychology, 30, 437-461.

Davids, K. \& Button, C. (2000). The cognition-dynamics interface and performance in sport. International Journal of Sport Psychology, 31, 515-521.

Davids, K., Handford, C., Bennett, S. \& Kingsbury, D. (2000). Perception-action coupling: Implications for practice organisation during acquisition of self-paced extrinsic timing tasks. Congres International de la SFPSSymposia. París: INSEP.

Davids, K., Handford, C. \& Williams, M. (1994). The natural physical alternative to cognitive theories of motor behaviour. An invitation for interdisciplinary research in sport science? Journal of Sport Sciences, 12, 495-528.

Delignieres, D., Nourrit, D., Sioud, R. et al. (1998). Preferred coordination modes in the first steps of the learning of a complex gymnastics skill. Human Movement Science, 17, 221-241.

Diedrich, F. J. \& Warren, W. H. (1995). Why change gaits? Dynamics of the walk-run transition. Journal of Experimental Psychology: Human Perception and 
Performance, 21 (1), 183-202.

Dijkstra, T. M. H., Schöner, G., Giese, M. A. \& Gielen, C. C. A. M. (1994). Frequency dependence of the action-perception cycle for postural control in a moving visual environment: Relative phase dynamics. Biological Cybernetics, 71, 489-501.

Ewing, J. L., Wolfe, D. R., Rogers, M. A., Amundson, M. L. \& Stull, G. A. (1990). Effects of velocity of isokinetic training on strength, power and quadriceps muscle fibers characteristics. European Journal of Applied Physiology, 61, 159-162.

Feldenkrais, M. (1985). Autoconciencia por el movimiento. Barcelona: Paidós.

Fitzpatrick, P., Schmidt, R. C. \& Lockman, J. J. (1996). Dynamical patterns in the development of clapping. Child Development, 67 (6), 2691-2708.

Garlando, F., Kohl, J., Koller, E. A. \& Pietsch, P. (1985). Effect of coupling the breathing and cycling rhythms on oxygen uptake during bicycle ergometry. European Journal of Applied Phsisiology, 54, 497-501.

Haken, H., Kelso, J. A. S. \& Bunz, H. (1985). A theoretical model of phase transitions in human hand movements. Biological Cybernetics, 51, 347-356.

Hall, K. \& Magill, R. A. (1995). Variability of practice and contextual interference in motor skill learning. Journal of Motor Behavior, 27, 299-309.

Hamill, J., Van Emmerik, R. E. A., Heiderscheit, B. C. \& Li, L. (1999). A dynamical systems approach to lower extremity running injuries. Clinical Biomechanics, 14, 297-308.

Hodges, N. J. \& Franks, I. M. (2002). Learning as a function of coordination bias: Building upon pre-practice behaviours. Human Movement Science, 21, 231-258.

Ingvaldsen, R. P. \& Whiting, H. T. A. (1997). Modern views on motor skill learning are not representative. Human Movement Science, 16, 705-732.

Jackson, S. \& Csikszentmihalyi, M. (2002) Fluir en el deporte: Claves para experiencias y situaciones óptimas. Barcelona: Paidotribo.

Kantz, H. \& Kurths, J. (1998). Nonlinear Analysis and Physiological Data. Berlin: Springer.

Kelso, J. A. S. (1999). Dynamic Patterns . USA: Massachusetts Institute of Technology.

Kelso, J. A. S. \& Jeka, J. J. (1992). Symmetry breaking dynamics of human interlimb coordination. Journal of Experimental Psychology: Human Perception and Performance, 18 (3), 645-668.

Kelso, J. A. S. (2000). Principles of dynamic pattern formation and change for a science of human behavior. In L. R. Bergman, R. B. Cairns, L. G. Nilsson, \& L. Nystedt (Eds.), Developmental Science and the Holistic Approach. Lawrence Erlbaum Associates Publishers.

Kelso, J. A. S. (2003). Understanding human motor behavior: Coordination dynamics. Proceedings of the $1^{\text {st }}$ Meeting of Complex Systems and Sport. Barcelona: International Journal of Computer Science in Sport.

Kugler, P. N., Kelso, J. A. S. \& Turvey, M. T. (1980). On the concept of coordinative structures as dissipative structures: I. Theoretical lines of convergence. In G. E. Stelmach, \& J. Requin (Eds.), Tutorials in Motor Behavior. Amsterdam.
Kurz, M. J. \& Stergiou, N. (2004). Applied Dynamic Systems Theory for the Analysis of Movement. Innovative Analyses of Human Movement (pp. 93-120). USA: Human Kinetics.

Large, E. W. (2000). On synchronizing movements to music. Human Movement Science, 19, 527-566.

Magill, R. A. \& Green Hall, K. (1990). A review of the contextual interference effect in motor skill acquisition. Human Movement Science, 9, 241-289.

Marin, L., Bardy, B. G., Baumberger, B., Flückiger, M. \& Stoffregen, T. A. (1999). Interaction between task demands and surface properties in the control of goal-oriented stance. Human Movement Science, 18, 31-47.

McGarry, T., Anderson, D. I., Wallace, A., Hughes, M. D. \& Franks, I. M. (2002). Sport competition as a dynamical self-organizing system. Journal of Sports Sciences, 20, 771-781.

McGarry T. \& Franks, I. M. (1996). In search of invariant athletic behaviour in sport: An example from championship squash match-play. Journal of Sports Sciences, 14, 445-456.

McGarry, T., Khan, M. A. \& Franks, I. M. (1999). On the presence and absence of behavioural traits in sport: An example from championship squash match play. Journal of Sport Science, 17, 297-311.

Mechsner, F. (2004 a). A psychological approach to human voluntary movements. Journal of Motor Behavior, 36 (4), 355-370.

Mechsner, F., Kerzel, D., Knoblich, G. \& Prinz, W. (2001). Perceptual basis of bimanual coordination. Nature, 414 (6859), 69-73.

Mechsner, F. (2004 b). Response to commentaries: Actions as perceptual-conceptual "Gestalts". Journal of Motor Behavior, 36 (4), 408-417.

Milliex, L., Calvin, S. \& Temprado, J. J. (2003). Recruitment of degrees of freedom in a synchronisation task: Result of a coalition of constraints. In W. I. Schöllhorn, C. Bohn, J. M. Jäger, H. Schaper \& M. Alichmann (Eds.), European Workshop on Movement Science. Mechanics, Physiology, Psychology. Köln: Sport Buch Strauss.

Nistch, J. R. \& Munzert, J. (2002). Aspectos del entrenamiento de la técnica desde la perspectiva de la teoría de la acción. Aproximaciones a un modelo integrador. In J. R. Nitsch, A. Neumaier, H. Marées \& J. Mester (Eds.), Entrenamiento de la técnica. Barcelona: Paidotribo.

Oullier, O., Bardy, B. G., Stoffregen, T. A. \& Bootsma, R. J. (2002). Postural coordination in looking and tracking tasks. Human Movement Science, 21, 147-167.

Oullier, O., De Guzmán, G. C., Jantzen, K. J. \& Kelso, J. A. S. (2003). The role of spatial configuration and homologous muscle activation in coordination between two individuals. Proceedings of the $1^{\text {st }}$ Meeting of Complex Systems and Sport. Barcelona: International Journal of Computer Science in Sport.

Pellecchia, G. L. \& Turvey, M. T. (2001). Cognitive activity shifts the attractors of bimanual rhythmic coordination. Journal of Motor Behavior, 33 (1), 9-15.

Rein, R. \& Simon, C. (2003). Influence of technique variation training on technique variability in long distance running. Proceedings of the $1^{\text {st }}$ Meeting of Complex Systems and Sport. Barcelona: International Journal of Computer Science in Sport. 
Riccio, G. E. (1993). Information in movement variability about the qualitative dynamics of posture and orientation. In K. M. Newell \& D. M. Corcos (Eds.), Variability and Motor Control. Champaign, IL: Human Kinetics.

Rutherford, O. M., Greig, C. A., Sargeant, A. J. \& Jones, D. A. (1986). Strength training and power output: Transference effects in the human quadriceps muscle. Journal of Sports Sciences, 4, 101-107.

Schmidt, R. C., Carello, C. \& Turvey, M. T. (1990). Phase transitions and critical fluctuations in the visual coordination of rhythmic movements between people. Journal of Experimental Psychology: Human Perception and Performance, 16 (2), 227-247.

Schmidt, R. A. (1982). Motor Control and Learning. A Behavioural Emphasis. Champaign, IL: Human Kinetics.

Schmidt, R. A. (1975). Motor Skills. New York: Harper \& Row.

Schmidt, R. C., O’Brien, B. \& Sysko, R. (1999). Selforganization of between-persons cooperative tasks and possible applications to sport. International Journal of Sport Psychology , 30, 558-579.

Schmidt, R. C., Treffner, P. J., Shaw, B. K. \& Turvey, M. T. (1992). Dynamical aspects of learning an interlimb rhythmic movement pattern. Journal of Motor Behavior, 24 (1), 67-83.

Schöllhorn, W. I. (2004). Applications of artificial neural nets in clinical biomechanics. Clinical Biomechanics, 19 (9), 876-898.

Schöllhorn, W. I. (2000). Applications of systems dynamic principles in technique and strength training. Acta Academiae Olympique Estonia, 8, 67-85.

Schöllhorn, W. I. \& Bauer, H. U. (1998). Identifying individual movement styles performance sports by means of self organizing kohonen maps. Proceedings of the XVI International Symposium on Biomechanics in Sports. Konstanz.

Schöllhorn, W. I., Röber, F., Jaitner, T., Hellstern, W. \& Käubler, W. (2001). Discrete and continuous effects of traditional and differential sprint training. $6^{\text {th }}$ Annual Congress of the European College of Sport Sciences. Colonia: Sport und Buch Strauss GmbH.

Schönherr, T. \& Schöllhorn, W. I. (2003). Differential learning in basketball. European Workshop on Movement Science - Mechanics, Physiology, Psychology. Cologne: Sport Buch Strauss.

Selles, R. W., Wagenaar, R. C., Smit, T. H. \& Wuisman, P. I. (2001). Disorders in trunk rotation during walking in patients with low back pain: A dynamical systems approach. Clinical Biomechanics, 16 (3), 175-181.

Shea, C. H. \& Kohl, R. M. (1990). Specificity and varia- bility of practice. Research Quarterly for Exercise and Sport, 61, 169-177.

Shea, J. B. \& Morgan, R. L. (1979). Contextual interference effects on the acquisition, retention, and transfer of a motor skill. Journal of Experimental Psychology: Human Learning and Memory, 5, 179-187.

Souchard, P. E. (1996). Stretching global activo (de la perfección muscular a los resultados deportivos). Barcelona: Paidotribo.

Stergiou, N., Jensen, J. L., Bates, B. T., Scholten, S. D. \& Tzetzis, G. (2001). A dynamical systems investigation of lower extremity coordination during running over obstacles. Clinical Biomechanics, 16, 213-221.

Temprado, J. J. \& Laurent, M. (1999). Perceptuo-motor coordination in sport: Current trends and controversies. International Journal of Sport Psychology, 30, 417-436.

Thelen, E., Corbetta, D., Kamm, K. et al. (1993). The transition to reaching: Mapping intention and intrinsic dynamics. Child Development, 64, 1058-1098.

Thelen, E., Corbetta, D. \& Spencer, J. P. (1996). Development of reaching during the first year: Role of movement speed. Journal of Experimental Psychology: Human Perception and Performance, 22 (5), 1059-1076.

Thelen, E. \& Smith, L. B. (1998). A Dynamic Systems Approach to the Development of Cognition and Action. Cambridge: Bradford Book MIT Press.

Thelen, E. \& Ulrich, B. D. (1991). Hidden skills: A dynamic systems analysis of treadmill stepping during the first year. Monographs of the Society for Research in Child Development, 56, (1, Serial No. 223).

Torrents, C., Balagué, N., Perl, J., Schöllhorn, W. I. (2005). Differential Training in Aerobic Gymnastics. Preprint.

Treffner, P. J. \& Kelso, J. A. S. (1999). Dynamic encounters: Long memory during functional stabilization. Ecological Psychology, 11 (2), 103-137.

Trockel, M. \& Schöllhorn, W. I. (2003). Differential training in soccer. European Workshop on Movement Science. Mechanics, Physiology, Psychology. Köln: Sport Buch Strauss.

Ulrich, B. D., Ulrich, D. A. \& Angulo-Kinzler, R. M. (1998). The impact of context manipulations on movement patterns during a transition period. Human Movement Science, 17, 327-346.

Weir, J. P., Housh, T. J. \& Weir, L. L. (1994). Electromyographic evaluation of joint angle specificity and cross-training after isometric training. Journal of Applied Physiology, 77, 197-201.

Wulf, G. \& Prinz, W. (2001). Directing attention to movement effects enhances learning: A review. Psychonomic Bulletin and Review, 8, 648-66. 


\title{
DINAMINIŲ SISTEMŲ TEORIJA IR SPORTO TRENIRUOTE்
}

\author{
Carlota Torrents ${ }^{1}$, Natalia Balague ${ }^{2}$ \\ De Lleida universiteto Katalonijos nacionalinis kūno kultūros institutas ${ }^{1}$, de Lleida, \\ Barselonos universiteto Katalonijos nacionalinis kūno kultūros institutas ${ }^{2}$, Barselona, Ispanija
}

\section{SANTRAUKA}

Mokslas, kaip žmogaus veiklos sritis, yra nuolatinis procesas. Anksčiau nustatytos ir skelbtos tiesos tikslinamos, kartais paneigiamos, kuriamos naujos žinios, teorijos, jos vèl tikrinamos. Vis dažniau siūloma pabandyti suvokti klasikinio mokslo, taip pat ir klasikinès treniravimo teorijos ribotumą. Šiandien dinaminiu sistemų teorija kaip metodologinị ịrankị pateikia kitokị požiūrị i organizmo funkcijų sudètingumo poreiškius bei siūlo naujus ir vertingus principus, kurie turètų būti taikomi sporto treniruotės tobulinimo vyksme.

Straipsnyje apžvelgiamos nūdienos mokslo naujovès, parodoma, kad užuot sportininko organizmą isivaizdavus kaip mašiną ar mechaninę sistema, i jo veiklą turi būti žvelgiama kaip i kompleksinę dinaminę sistemą kaip i sisteminę saviraišką, morfologiniais, fiziologiniais, psichologiniais, biomechaniniais veiksniais pasireiškiančią per sportinę veiklą. Ši kompleksiškumą lemia pradinès sąlygos ir treniruotės užduočių kaitumas. İ treniruotumo didẻjimo mechanizmą žvelgiama kaip ì saviraiškos procesą, transformuojantị poveikio stimulą ir judèjimą. Taigi treniruotės krūviai ir visos priemonès turi stimuliuoti bendrają saviraišką kitaip tariant, keičiant aplinkos ir treniruotès sąlygas sportininkas ir jo veiklos stilius keisis norima treniruotumo kryptimi. Individualizavimo principas turi būti grindžiamas ne tik igytomis, bet ir perteikiamomis žiniomis gerinant sportininko treniruotès ir varžybinę veiklą.

Taigi dinaminių sistemų teorija keičia mūsų supratimą apie treniruotumo didejjimo mechanizmus, formuoja naują požiūri i sportinę veiklą ir treniruotés metodus, skatina mokslininkus ir trenerius ieškoti tinkamesniu sprendimų optimizuojant sporto treniruotės vyksmą.

Raktažodžiai: saviraiška, kaitumas, fliuktacija, pastovumas.

Gauta 2005 m. balandžio 20 d.

Received on April 20, 2005

Natalija Balaque INEFC Barcelona Av. de l'Estadi, s/n 08038 Barcelona E-mail nbalague@gencat.net Tel +34934255445 